\title{
INTERNATIONAL LAW IN THE CONTEXT OF ECONOMIC GLOBALIZATION
}

\author{
Andrey A. Mamedov \\ Peoples' Friendship University of Russia \\ Law Institute \\ 6, Mikluho-Maklaya, Moscow, Russia, 117198 \\ Vera N. Batova \\ Penza State Technological University \\ 1a/11, Prospect Baydukova / Gagarin Str., Penza, Russia, 440039
}

The article examines the international legal integration regulation of relations in the sphere of economics and finance context of globalization. The modern era - an era of globalization, which includes the highly dynamic development of integration processes in various areas of activity of the state. Globalization is an objective the emergence of supra-national / transnational elements of legal regulation. More and more questions of domestic jurisdiction transferred to the states under the international legal regulation. In the context of globalization in the development of the law is a tendency of formation of international integration law. Therefore, considering the legal regulation of relations in the sphere of economics and finance in the modern period, we can not ignore world integration processes as a result of globalization.

Key words: economy, finance, banking, international law, international rules-principles, globalization, global economic space, unification of the law, integration, agreement

Funding information. The publication has been prepared with support of the "RUDN University Program 5-100".

\section{INTRODUCTION}

At the last decades of the XX century and at the beginning of the new third millennium globalization is increasingly becoming one of the main determinants of civilizational development. A new turn has begun at the history of human civilization (Klepatsky, 2002:37). It differs from previous eras primarily by a steep change at the trajectory of the development of all mankind, a rapid acceleration of the rate of change at the life of each people. Already, we can assume that the new century will be called the century of globalization or the century of global civilization, because today man began to associate himself with the whole of mankind at the face of numerous global threats, before the need to solve the most difficult tasks of survival, space 
exploration, etc., where uniting the efforts and resources of the entire world community, coherence of actions and mutual understanding ${ }^{1}$.

To solve these problems, it is necessary, from the one side, to radically change existing social systems, and to the other, to lay the foundation of a new general planetary structure of society that meets the needs of all mankind. The processes of globalization affect all spheres of human activity, and the legal systems of national states are also subject to them (Bogatyryov, 2013:128-133). It has already become evident that the law is standardized and unified within the whole planet.

When searching for solutions to the problems of globalization of law, scientists actively rely on the rich world spiritual heritage obtained from past generations of all mankind and at the same time use their own national-legal experience (Bogatyryov, 2006:51). The worldwide spiritual heritage is a knowledge of the laws of the development of nature and society (science), emotional perception of the surrounding world (culture), sets of communication' rulles (morality), ideals and motives of activity (ideology and morality), the system of regulation of social relations (law and morality), the ways and forms of the transfer of spiritual heritage from generation to generation (education).

As for the national legal heritage, at the modern turning point, it became necessary to reassess some of its provisions that have come into conflict with the objective reality and are expressed in the change of scientific-legal paradigms, the renewal of the values contained in the law, the collapse of the former and the emergence of new ideals, the search for effective legal ways to regulate social relations, revolutionary changes at legal education. The reassessment of the national legal heritage is a painful and lengthy process. It is associated with the collapse of habitual stereotypes of thinking and behavior, the emergence of many alternative positions, the sudden revival of long forgotten and rejected views (Bogatyryov, Gorshkova, 2010:51).

At the same time, it is necessary to take into account that it is the law has its basis has all the prerequisites for globalization, since it is less than other social regulators tied to national characteristics and more quickly changed.

However, for a long time at all countries of the world, studying law, scientists focused on the national peculiarities of legal systems, which indicates nationalism at the legal sphere. Today, however, you should study the parties, unifying the legal system, their internationalizing.

The need for a reorientation of the research paradigm in the legal sphere is objectively determined by the needs of the regulation of the emerging new global social structures, within which the old legal national regulators are no longer active.

Thus, the formation of international global law and the integration of all national legal systems are objective necessity and regularity.

\footnotetext{
${ }^{1}$ Bogomolov O.T., Call to a world order // Independent newspaper, 1 January 2000.
} 


\section{THE DEVELOPMENT OF INTERNATIONAL LAW AT THE PERIOD OF GLOBALIZATION}

\section{The impact of globalization at international law}

The modern scientific and methodological approach to the study of social phenomena, social institutions, processes and systems allows us to interpret law as a complex social phenomenon. As professor I. Farkhutdinov notes, law is primarily a dialectical unity of subjective and objective law, legal relations and legal norms. Ultimately, the entire course of human history predetermines the nature of the evolution of law ${ }^{2}$.

In the conditions of the transforming world, phenomenally qualitative changes take place in the international-legal system. They are caused by the emergence of new legal subjects both at the national and international levels.

At the era of globalization, there is a revolution in the historical movement, which manifests itself in increasing the significance of the conscious development factor (scientifically known objective regularities and tendencies) over the former spontaneity of the evolution of the society, its economy, law, ideology, politics, and etc.

This process was most contoured at connection with the scientific-technical revolution (NTR), when science turned into a decisive force for the growth of productive forces and labor productivity at the creation of material benefits. At the middle of the twentieth century began to occur, especially in advanced countries, a change in the 'axial principle' of the history of modern progress. If earlier a such principle was a change of the form of ownership of the means of production, now such decisive factors of social progress and economy can be considered intellectual property, primarily high technology.

G.I. Tunkin stresses that "the rapid pace of the development of ties between states has now led to the fact that the international law obviously doesn't manage "to cover" adequately all new and new areas of the international relations and new international problems" (Tunkin, 1982:628).

The state as the main subject of international law and international law as a universal regulator of legal relations, primarily of an interstate character, are, as figuratively expressed by Lukashuk I.I., literally under the targeting fire of globalization, which directly affects the character and functions of the state and law as such: law of both the nationl and the international (Lukashuk, 2002:118). At the same time, the legal system of each state remains its most important characteristic, an integral element. At the same time the legal system of each state still remains her major characteristic, the integral element.

Professor Lukashuk I.I. became the first Russian scientist, who on a conceptual basis developed problems of influences on international law of forward globalization processes. At the same time, one of the most important problems, in his opinion,

\footnotetext{
${ }^{2}$ Koh, H. (1996), Transnational Legal Process // Nebraska Law Review, p. 75.
} 
is the harmonization of the norms of international and internal law, which requires timely legal regulation and appropriate legal regulation of relations between various subjects of international law (Polenina, Gavrilov, Koldayeva, 2004:7).

Speaking about the further development of international law, I.I. Lukashuk specifically noted the need for a special branch of knowledge - international-legal prognostics. As an important prerequisite for the development of international-legal prognostics, he called the achievements of the general theory of international law.

Specifically - about the importance of prognostics at the light of further changes in the sphere of international legal personality (Lukashuk, 2005:518). At these conditions the social role of the law as spheres of freedom and at least morality, as a battery of the achievements of reason, culture and enlightenment at the age-long striving of peoples for peace, freedom, justice, equality grows, and the most important institution of modern legal systems is not only the property right, but also human (Lukashuk, 2002:60). By the way, the concept of state and law at the doctrinal plan is comparable to the concept of law at international relations (Kalamkaryan, 2002:60).

The renewed philosophy of law, in particular, attaches great importance to the interpretation of genesis and the functioning of the law of the role it played and plays in the formation of the personality, its all-round development and the realization of its capabilities (Farkhutdinov, 2010:415).

\section{Integration is the determining factor of the formation of a uniform global legal order}

Powerful integration processes taking place in the second half of the 20th century in the sphere of national economies, information technologies, in the social environment, could not but affect the law as such. The emergence of the world system of economics and law calls the need for integration of state-political systems, which is complicated by structural transformations of national legal systems (Alekseev, 1999:40).

Integration processes repeatedly increase the possibilities of material production, creative work at an open society, the use of the international division of creative activity and the free exchange of achievements at the field of spiritual and material culture of the peoples of the world. They not only significantly increase rates of social progress, but also create real prerequisites for the elimination of interstate, socioeconomic and political, racial, national and religious antagonisms, create the way for strengthening of the international (Lukashuk, 2002:5).

"Forming a uniform legal order, protected by a uniform statehood, - believes L.S. Yavich, - is a kind of real mean for the democratic regulation of social relations at the international level. This mean will ensure the survival and further development of human civilization" (Yavich, 2003:40).

However, the path to integration of states is complex and requires, among other things, a new political, legal and general awareness of the new reality. The question of the forms of integration of states, their unification and alliances requires 
further scientific-practical development. It must be assumed that any regional, and then global processes of integration of states will not be connected with the liquidation of existing states, their absorption by a unitary state.

Most likely it will be a question of formation of confederative associations (such as of the EU) and as a result in the near future - the World Confederation of the States (WCS) on the basis of reorganization of the United Nations into a public entity or acting in concert with the UN, which will include the countries of the WCS and those states and which did not enter the WCS. Such a bold statement of the question requires a new doctrinal approach to the issue of state sovereignty and the right of each nation to an independent statehood, about the correlation of these principles (Tikhomirov, 2004).

In new conditions common interests of the states which are still main subjects of international law are put in the forefront. At the same time the priority of interests of the international community doesn't mean infringement of interests of the states. The task consists in achieving an optimum combination of interests.

\section{Globalization of the world system of law: positions for and against}

Regardless of how its opponents and supporters regard globalization, it must be recognized that it has already clearly changed the world system, generating new problems in international law, including in the sphere of international personality. Some aspects of the impact of globalization on national economies deserve special mention. First of all, we note the extremely high growth rates of foreign direct investment, far exceeding the growth rates of world trade. These investments play a key role in the transfer of technology, industrial restructuring, the formation of global enterprises, which has a direct impact on the development of international law (Farkhutdinov, 2005:463).

The creation and maintenance of the functioning of the new world order requires a higher organization of the world system, a substantial increase in the degree of its controllability. Today, this is a key global problem, and international legal regulation of other global problems depends on its solution (Lukashuk, 2002:5).

An important obstacle to the formation of a new world order is the lag in political thinking from the reality of our time, which also manifests itself in the recurrence of an outmoded legal consciousness. A characteristic feature of the modern process of forming a new world order is its multilateral nature, participation in the process of a wide range of states, in which the $\mathrm{UN}$ is called upon to play the central role. Within its framework, the collective efforts of the states succeeded at the turn of the 21 st century to form the basis of a new world ocof resolutions adopted by the General Assembly in 2000 at the historic session - the "Millennium Session", including the Millennium Declaration of the UN.

It is very important that the basis of the new world order have to compose the goals and principles of the UN Charter that have proved to be an enduring and universal nature (Lukashuk, 2005:230). Only on this basis is it possible to establish a just 
and lasting peace that exists on conditions favorable to sustainable development for respect for the rights of peoples and an individual (Farkhutdinov, 2004:28). In other words, an important role in establishing a new world order is assigned to international law and legitimcy as a whole, i.e. the task is "to increase respect for the rule of law in international as well as internal life" ". In this position, the idea of the unity of international and internal legitimacy was expresse (Lukashuk, 2002:118).

The phenomenon of the development of international law is a significant gap between two interrelated and interdependent processes: law-making and lawrealization. The law-making process is progressively more progressive. At the same time, the mechanism of the implementation of norms is unforgivably slowly improved. In order to improve the effectiveness of international law, it is necessary to improve the mechanism of its operation, that is, the solution of global problems requires an increase in the level of controllability of the international system on the basis of international law. The cardinal step in its improvement was, for example, the allocation in a special category of responsibility for serious breaches of obligations arising from peremptory norms of general (Farkhutdinov, 2009:5) international law. We are talking about commitments to the international community as a whole (Lukashuk, 2004:432).

In practice, all social scientists acknowledge the objective nature of globalization, focusing on its economic component. They believe that today it is in the economy that ties between states become closer, mutual dependence is tougher, and the need for multilateral coordination is more urgent (Maksimenko, 1999:94).

The development of globalization leads to economic phenomena such as the permeability of interstate borders for the free movement of financial flows, the movement of goods, services, technology, labor, that is, to the extension of the mostfavored legal regimes in these areas. States with a market economy converge on the level of prices for goods, profitability of enterprises and salaries, the trend towards international outsourcing is growing, the number and size of mergers of companies within states and at the international level is growing, accompanied by restructuring and a decrease in the number of employed labor (Egorov, 2014:1087). As a result, universalization of market relations, through the establishment of unified economic principles, customs and legal norms for subjects of international economic relations, and as a result - the strengthening of the interconnection and interdependence of national markets of states.

The proponents of globalization note a number of advantages that have taken place due to globalization. In their view, globalization weakens the prerequisites of conflicts, contributes to world peace, the establishment and strengthening of democracy, the development of a global civil society, accountability of the authorities and the supremacy of law. World trade promotes the "discovery" of national borders, the

\footnotetext{
${ }^{3}$ Resolutions and Decisions adapted by the General Assembly during its fifty-fifth Session. 2001. Vol. IV, pp. $4-5$.
} 
development of production, the spread of western standards of consumption, way of life, attitude to other states. Thanks to globalization, there has been an increase in productivity in agriculture, healthcare has improved, due to technical progress, many new materials have been developed, which reduced the need for raw materials, reduced material consumption in those industries where natural raw materials could not be replaced with synthesized raw materials. At the same time, there is a rapid growth in the production of explored reserves of minerals.

Let us also point out the negative aspects of the process of economic globalization. The well-known financier J. Soros warns that the economic function of modern capitalism not only begins to dominate over other spheres of social life, but also makes the main and almost absolute value the motive of profit receiving (Soros, 1999:329). At economic relations, the speculative-usurious principle of profit is increasingly dominated instead of competitive-productive. Globalization in the economy leads to uneven development of developed and developing countries, leads to the concentration of power "in the hands of the rich North", to the exploitation of labor by capital and the stratification of society: enriching the rich and impoverishing the poor. Informatization and automation of production lead to the approval of an economy that does not need workers. In industrial sectors, the production policy is determined by a rather narrow circle of highly professional specialists and intellectuals, which gives rise to "elitism" as the organizing principle of economic life, and, consequently, the education system.

Employers are in greater need of the most productive staff in the context of globalization, which is directly related to education. To achieve high labor productivity in any state, TNCs are interested in attracting qualified personnel and retaining the best workers.

TNCs are forced to offer a better pay system than national companies, to reach agreements with trade unions. In turn, this forces local companies to raise standards of work with personnel.

In the conditions of the information-technological revolution, only states whose citizens have a sufficiently high level of education can claim a worthy place. The increasing material stratification of society in both developed and developing countries is largely affected by the unequal access of citizens to education.

Only highly qualified citizens can maintain their social status or win in the process of globalization, with a significant number of workers are at risk of being among the unemployed (Moiseyev, 2006:234). It would be wrong to shield itself from globalization simply because it is based on western principles of building a business through 'network structures', management, production and distribution (Moiseyev, 2015:72), which proved their economic efficiency. It is also not productive to create a model for imitation in the form of a model of western civilization, which will objectively lead to an economic backwardness. Today, globalization already exists and states need to actively participate in it and influence international processes for a successful existence. 
According to the british historian, the West was "destined ... to do something not just for themselves, but for the whole of mankind" — to erect "scaffolding in which all previously scattered societies would have built one common building" (Toynbee, 1995:168) of human civilization.

Thus, the role of law in the modern world is growing, and it represents an objective pattern of the global world order. The question arises: "to what extent does the law in general and legislation in particular undergo changes in public life - kind of automatically, following changes in the state or on own regularities; whether the system of the legislation is re-created or is it possible continuity of its principles and branches, whether the reforms are reducible to the restructuring of the regulatorylegal system or include changes in the understanding of law, in legal consciousness and motivation, in legal institutions. Each country gives the answer to this question" (Tikhomirov, 1996:435).

\section{Strengthening the role of international law in the context of economic globalization}

In the context of globalization, when the interconnection and interdependence of states, their economies reaches an unprecedented level, the law fulfills the functions of 'normative integration'. The effect of the law becomes even more universal, as the need for similar legal principles and decisions increases, which also requires the expansion of the field of coordinated legal development. "The common legal framework is largely formed and protected by international law, which acquires a new meaning" (Farkhutdinov, 2003:143).

The abovementioned problems are united by the fact that they are of a global nature and can only be solved by the joint efforts of all states. For this it is necessary, as professor I.I. Lukashuk points out, a higher level of management of social processes both at the national and global levels. Substantial improvement in the management of institutional systems in accordance with the norms of international law, as already noted, is an urgent matter. As a result, the role of such management tools, as international organizations and international law, will increase. Of particular importance is the interaction of international and internal law of states. Interaction of the international and internal law of the states is of particular importance (Lukashuk, 2005:116). In this context, it is difficult not to agree with the scientist's opinion that "globalization blurs the line between the internal and external spheres of activity, between domestic and foreign policies" (Kochetkov, 2005:211).

Similar concepts, existing in the domestic legal science, argue that in the context of globalization the concept of objective borders of international law has to be a thing of the past, as it creates rights and obligations not only for states but also directly for individuals and legal entities, has a direct effect on in the domestic sphere (Marochkin, 1997:20)."Supporters of this concept can not ignore, - I.I. Lukashuk (2001:68) notes rightly, - the obvious facts, recognizing that international law has a direct effect on the territory of states as part of the national legal system. Here it is 
impossible to speak about direct action of international law, because it is carried out with the sanction of the state, as part of its legal system". That is it is about difficult process of incorporation, "inclusion" of norms of international law in the national law (Dmitriyeva, Lukashuk, 1995:7).

It should relate to the problem of incorporation, which really is extremely difficult (Lukashuk, 2001:9). Differences in legal systems, legal cultures and legal consciousness greatly complicate the problem. A specialist in this sphere, Professor at the University of Toronto K. Knop writes: "The domestic interpretation of international law is not the same everywhere. Ideally, we are dealing neither entirely international nor entirely national, but with a hybrid expressing the relations between them" (Knop, 2000:524).

A well-known expert at this sphere, Professor R. Müllerson, figuratively noted that the inclusion of international norms in the legal system of the country "does not mean that the lion becomes a cat" (Muellerson, 2000:199). Being 'included' in the legal system of the state, international norms act as part of this system and are provided by the mechanism inherent in this system. The mechanism of operation of international law is not suitable for this (Lukashuk, 1997:34).

In the organizational-legal sense, the successive transition of most countries from closed national economies to an open economy, facing the external market, causes a change in the state's economic function. According to Professor V.M. Shumilov, one can speak to some extent about the convergence of national economies on the principles of liberalism and the free movement of capital and services. The emerging global uniform economic space requires that the idea of liberalization has been issued and recorded by political and legal means. For example, this should be done within the framework of the World Trade Organization (WTO) (Shumilov , 2003:48).

The globalization of the world economy, Professor V.M. Shumilov argues further, creates prerequisites for the formation of a political-legal superstructure corresponding to a common economic space. In fact, the scientist is talking about the creation of a global social system in which "their", global problems have ripened, their interests are being formed, their institutional and regulatory mechanisms, possessing supranational properties (Shumilov, 2003:20).

Supporters of direct regulation of international relations by interstate relations sometimes refer to the concept of a uniform european legal space. However, this reference can hardly be, as I.I. Lukashuk, convincing. The European Union (EU) means a high degree of unity not only of common but also of specific norms of international law in the relations of states, a significant level of harmonization of their national legal systems and, and certainly, a thorough interaction of international and national law (Abashidze, Lukashuk, 2001:116).

By incorporating in Russian national law, they do not lose, also emphasizes O.I. Tiunov, international-legal quality, i.e. remain part of the international-legal system (Tiunov, 1999:254). Consequently, norms that are initiated by international law occupy a special position in the national legal system. International-legal norms operate within the framework of this system in close connection with national law. 


\title{
III. THE DEVELOPMENT OF INTERNATIONAL LAW IN THE CONTEXT OF GLOBALIZATION
}

\author{
Integration aspect of the development of law
}

The modern epoch - this is the epoch of globalization, which includes the highly dynamic development of integration processes in various areas of the state.

With the globalization of national economies to integrate into a united planetary space with a universal system of economic institutions and the interaction of markets. In our view, globalization is a process of erasing the boundaries not only economic between states, but also the national jurisdictional boundaries.

Legal aspect of globalization is manifested in our opinion, primarily in the fact that more and more questions of domestic jurisdiction transferred to the states at a supranational regulation and, as a consequence, an increase in the number of international treaties governing relations in various spheres of state activity. Formation of a global economic space - the most important aspect intensifies the process of erasing the borders of national jurisdictions.

Therefore, considering the legal regulation of relations in the economic and financial segments of the activities of states in the modern period, we can not ignore the world integration processes in the globalization process, which leads to the creation of a holistic legislation, following a single legal logic and requires consideration of both the neoliberal global trends and diverse nature of national legal systems.

Globalization objectively leads to the emergence of supranational / transnational elements of legal regulation, strengthening in law the role of the international integration aspects.

In the development of law in the context of globalization are the following main trends of its development, primarily:

- first of all - the trend towards unification of the law, which manifests itself in an effort to develop a common, comprehensive approach to law, meaning the introduction in the legal systems of the states the uniform, unified the norms of law;

- secondly - this application for legal regulation of international normsprinciples with the legal ideas put in them: general legal principles (principles of equality, justice, humanity, and others.), as well as the principles enshrined at internationally - legal acts. In the context of economic globalization, namely international norms-principles play an increasingly active role in system of legal regulatory means in various segments of management of economy and finance by the state. The normsprinciples, which differ from the usual norms of law by a much higher level of generalization, it is in the conditions of integration of the economies of states that they perform the regulatory functions of the legal impact on relations in various segments of the life activity of states. In the conditions of economic globalization the tendency is traced to more widespread formation and greater use of international norms-principles of law as regulators in the area of economic and financial relations. These relations, in particular, should include the relations between the state and transnational corpora- 
tions, mediated through norms-principles of partnership and cooperation in solving common economic problems that play an active role in the system of legal regulatory means used at the global and regional levels;

In third - law in the context of globalization is becoming more complex system and it is impossible to provide everything in laws therefore the jurisprudence role a judicial precedent in the solution of the questions connected with legal regulation of the economic and financial relations inevitably raises.

At the same time, it should be noted that the science of international law and treaty practice concerning the conventional norms-principles of international proceeds from this that the uniform imperative principle of conscientious observance of the international obligations acts (for international contracts, it is called as the principle of "pacta sunt servanda").

\section{Development of legal regulation of international trade turnover}

For solution of problems, arising in connection with formation of uniform world economic and financial space, also requires creation of uniform legal space. In the conditions of the globalization of the world economy, it is globalization of legal space will contribute to leveling features of national legislation as a result of the application of uniform rules generated international integration law.

Understanding the principles of international law allows to simplify the integration process of the legal regulation of relations in the sphere of economics and finance in the context of economic globalization, including the conclusion of contracts, determination the conditions of their execution and rapid resolution of any dispute between the parties.

The complex governed also the standards regulating process of the conclusion and performance of the international commercial treaties develops within the international integration law, his institute of legal regulation of international trade, or Lex mercatoria.

So in the 90th of the XX century has appeared several legal documents which are accurately formulating the norms-principles of international trade recognized by the parties of international trade as the norms of law operating in this segment of world economy. It also allows to use them as the international legal acts of arbitration for permission of concrete disputes, including:

- The UNIDROIT Principles for International Commercial Contracts, 1994 (Hartkamp,1994:16);

- The Principles of European Contract Law, as amended by 2003 (Lando, Clive, Prum, Zimmermann, 2003);

- A set of principles, rules and standards Lex mercatoria (CENTRAL), as amended by 2003 (Berger, 1999).

The UNIDROIT principles were prepared by International Institute for the Unification of Private Law (UNIDROIT) and published in 1994. The document is not an international agreement, but because of the credibility of the organization that pro- 
duced it, quite often used in the preparation of international contracts and the resolution of international commercial disputes. Principles of European Contract Law developed within the European Union for the purposes of European legal integration.

Principles of European Contract Law developed within the European Union for the purposes of European legal integration. A set of principles, rules and standards Lex mercatoria was developed in the framework of the project Centre for Transnational Law (CENTRAL).

International norms-principles regulated in the above documents are universal, thus, their application isn't influenced by features of the national law of participants of contractual relations, and that is why they are used in international arbitration in resolving foreign trade disputes (Schmitthoff, 1963). This law-making process is being developed, there is a constant revision of norms-principles because of the need to respond to the constant changes in the structure of international commercial transactions, and as a result, create more and more rational norms that correspond to the current, constantly changing conditions of international trade turnover.

The modern legal regulation of international trade has overcome the 'legal order of many national legal systems' that slowed the development of Lex mercatoria.

The processes of globalization had exerted a positive impact on the formation of modern legal regulation of international trade, as a result of which it acquired:

1) the universal character;

2) flexibility and the possibility of dynamic growth;

3) non-formalization and rapid development;

4) reliance on trade custom and practice.

The complex of norms that make up Lex mercatoria and ensuring the regulation of international trade is quite extensive and includes, in our opinion, the following: general principles of law, norms-principles documents of international organizations, broadly defined customs and usages of international trade, arbitration awards, international conventions, model laws of the international legal character, etc.

It is at Lex mercatoria that current trends in the development of law for regulating international economic (predominantly trade) relations were reflected, with the ever growing dynamics of world economic relations and a certain lag in the development of national legislation that ensures their regulation.

In the conditions of globalization, the creation of a united economic space exactly Lex mercatoria provides necessary regulation of international trade transactions, removing certain contradiction international nature of such transactions, and their regulation by national law, and allows to exclude the transaction expenses, associated with the application of national law to transnational trade relations, which may hinder the development of the global market.

\section{International-legal regulators of international standardization}

Major sectors of the world economy, following the rapid development of world trade, especially e-commerce, have become global. 
As this trend affects the trade balance of countries, and therefore the living standard of living and welfare of the population of countries, the need for integrated legal regulation in the sphere of standardization, as an important component of the state's foreign economic activity in the global market, has increased dramatically.

The growing role of international standardization in the development of the national economy in these conditions has got really planetary character due to the constantly growing competition of national economies as a result of economic globalization, which requires taking into account the provisions of international standards in the promotion of national products to the world market

The last decade of the 20th century was caused by the revolutionary development of world economic relations, establishing new international norms-principles of legal regulation, unified mandatory legal regulators for the standardization of products having direct effect, and prohibiting their establishment unilaterally, restricting world trade, especially in connection with the formation of free trade zones.

Recognized on the basis of international standards of quality of national products at a competitive price has now become the purpose of the national economy.

At the basis of the practical implementation of unification legislation in the field of international standardization are international norms-principles, fixed in the Agreement on Technical Barriers to Trade (Marrakech, 15 April 1994):

- guarantee of transparency of procedure of standards' creation;

- established standards requirements should not create obstacles to the circulation of products in international trade.

Practical implementation of the unification legal norms in the sphere of international standardization is determined by the requirements of the Agreement on Technical Barriers to Trade (Article 4 "Preparation, Adoption and Application of Standards", item 4.1), in accordance that Members shall ensure that their central government standardizing bodies accepted and complied with the Code of Good Practice for the preparation, adoption and application of standards, given in Annex 3 to this Agreement (referred to in this Agreement as the "Code of Good Practic").

They undertake such reasonable measures available to them to provide acceptance and observance of that the Code of Good Practice is adopted and followed by local governmental and non-governmental standardization bodies within their territories, and by the regional standardization governing bodies of which they are members they or one or more governing bodies within their territories are. In addition, members do not take measures that directly or indirectly require such governing bodies or encourage them to act in a manner incompatible with the Code of Good Practice. 
The obligations of Members with respect to compliance of standardizing governing bodies with the provisions of the Code of Good Practice apply irrespective of whether or not a standardizing body has accepted the Code of Good Practice ${ }^{4}$. Thus:

- National authorities on standardization provide that technical regulations weren't developed, weren't accepted or weren't applied so that to create or lead to creation of excessive obstacles in international trade. For this purpose technical regulations don't make more limiting impact on trade, than it is necessary for achievement of the lawful purposes, taking into account risks which would arise when such objectives aren't achieved. Such lawful purposes are, inter alia: requirements of national security; prevention of deceptive practice; protection of health or safety of people, life or health of animals or plants, or environmental protection. National authorities on standardization provide that at assessment of similar risks such factors as, by inter alia, the available scientific and technical information, appropriate technology or intended end use of goods were considered;

- when relevant international standards exist or their completion is imminent, National standards body use them, or the relevant parts of them, as a basis for their technical regulations except when such international standards or relevant parts would be an ineffective or inappropriate means for achievement of the set lawful objects , for instance because of fundamental climatic or geographical factors or fundamental technical problems;

- when the corresponding international standard is absent, or maintenance of the developed technical regulations doesn't correspond to maintenance of the corresponding international standards and if the technical regulations can make essential impact on trade of other members, members:

1. Publish at the corresponding early stage the notice in the press of alleged introduction of concrete technical regulations to give the chance to interested parties in other national authorities of standardization to get acquainted with him;

2. Through the Secretariat notify other national authorities of standardization on the goods covered by the developed technical regulations, accompanying the notice with the short indication of the purpose and justification of the developed technical regulations. Such notices are published at the corresponding early stage when amendments and comments can be still made are taken into account;

3. On demand provide to other national authorities of standardization detailed descriptions or texts of the developed technical regulations and, whenever possible, specify sections which significantly differ from the corresponding international standards;

4. Without discrimination provide to other national authorities of standardization the reasonable period of time for preparation of remarks by them in writing, dis-

\footnotetext{
${ }^{4}$ The Code of Good Practice. available at http://www.wto.org/english/docs_e/legal_e/17-tbt.pdf. (visited 6 November, 2017).
} 
cussions of these remarks on demand and accounting of these written remarks and also results of these discussions.

\section{Convergence of international-legal regulation of bank activity}

For last decade high rates of innovations in the financial markets and internationalization of financial flows have changed shape of banking almost to unrecognizability. The traditional practice of banking based on attraction of deposits and granting the credits is only a part of activity of bank today, and often the least profitable. Modern banks were beyond traditional credit and deposit operations and have established the presence practically at all segments of a financial system. Innovative process has led to increase in a variety of financial instruments which markets constantly extend.

Today the new, based on information technology types of bank activity are the main sources to profitability of banks. Use of financial innovations: securitization of assets, broad application of 'off-balance' financial instruments such as options, guarantees and letters of credit, not only is a zone of the increased risk in activity of banks, but also is fraught with the complex problems concerning management of the arising risks and, as a result, the corresponding segments of the financial market, are very unstable. Consequences of financial destabilization are big and are expressed both in slowdown in economic growth, and in destruction of public trust to the financial markets.

Today owing to globalization of economy in general, including internationalization of financial flows and introduction of innovations in the financial markets, the fundamental problem in banking consists that on the one hand, adequate freedom of banks in decision-making under changes of market conditions of activity allows them to compensate jumps of an environment, but from another - concentration of bank risks as a result of bank activity leads to increase in instability of the banking sector in general and his main components - banks. The correlation between various types of risk both within separate bank, and in scales of a banking system has increased by orders and became more difficult. Legal regulation of activity of banks in the conditions of the competitive and unstable market became extremely difficult process.

It is, first of all, about the integrated standard legal massif. The states cooperate with the purpose of creation, development and use of the necessary internationallegal norms-principles, governing the relations, influencing basic factors of financial stability and solvency of participants of the financial market such as: sufficient equity; existence in the property of free assets; formation of reserve funds; placement of funds of reserve funds in the 'covering' assets; providing a standard ratio between assets and obligations (a solvency margin); maintaining systems of the international accounting and reporting, implementation of investment activities, financial control; restriction of single risk; tariff policy. 
All this throws down a challenge to traditional approaches to legal regulation of bank activity and demands sound realization of the ideas Basel process ${ }^{5}$ in the legal sphere - use of the unified legal regulators of bank activity: Basel international norms-principles.

To such international norms-principles are, first of all, the principles regulated in documents of an international-legal nature:

- International Convergence of Capital Measurement and Capital Standards: A Revised Framework ("Basel-2") ${ }^{6}$. Norms-principles of the Agreement 'Basel-2' grouped in three main components (pillars), interconnected, strengthen and complement each other to achieve an united goal - improving the financial stability of banks:

1. Minimum capital requirements.

2. The supervisory review process.

3. Market discipline;

- 20 other international-legal documents, issued by the Basel Committee, the norms of which regulate banking supervision, financial monitoring, management of banking risks and cross-border banking transactions ${ }^{7}$ :

1. Part B of the Amendment to the Capital Accord to Incorporate Market Risks, January 1996, Final.

2. Core Principles for Effective Banking Supervision, September 1997, Final.

3. The Core Principles Methodology, October 1999, Final.

4. Risk Management Guidelines for Derivatives, July 1994, Final.

5. Management of Interest Rate Risk, September 1997, Final.

6. Risk Management for Electronic Banking, March 1998, Final.

7. Framework for Internal Controls, September 1998, Final.

8. Sound Practices for Banks' Interactions with Highly Leveraged Institutions, January 1999, Final.

9. Enhancing Corporate Governance, August 1999, Final.

10. Sound Practices for Managing Liquidity, February 2000, Final.

11. Principles for the Management of Credit Risk, September 2000, Final.

12. Supervisory Guidance for Managing Settlement Risk in Foreign Exchange Transactions, September 2000, Final.

13. Principles for the Management and Supervision of Interest Rate Risk, January 2001, For Comment.

14. Risk Management Principles for Electronic Banking, May 2001, For Comment.

\footnotetext{
${ }^{5}$ The Basel committee on bank supervision. available at htpp://www.bis.org/publ/bcbs 128. pdf. (visited 6 November, 2018).

${ }^{6}$ International Convergence of Capital Measurement and Capital Standards: A Revised Framework ('Basel2'). available at htpp://www.bis.org/publ/bcbs128.pdf. (visited 6 November, 2018).

${ }^{7}$ The international legal documents issued by the Basel committee on bank supervision, available at: htpp:// www.bis.org / bcbs / publ / index. htm. (visited 6 November, 2018).
} 
15. Internal Audit in Banks and the Supervisor's Relationship with Auditors, August 2001, Final

16. Customer Due Diligence for Banks, October 2001, Final.

17. The Relationship between Banking Supervisors and Banks' External Auditors, January 2002, Final.

18. Supervisory Guidance for Dealing with Weak Banks, March 2002, Final.

19. Management and Supervision of Cross-border Electronic Banking Activities, October 2002, For Comment.

20. Sound Practices for the Management and Supervision of Operational Risk, February 2003, Final.

Provisions of Basel-3 offer new international legal regulators: standards of the capital, a ratio loan and equity, liquidity for strengthening of regulation, supervision and a risk management in the banking sector. Standards of the capital and new buffers of the capital will demand from banks of the bigger size of the capital and also bigger quality of this capital in comparison with the standards adopted in Basel-2. The new relation of the capital to borrowed funds enters a risk-free basis for calculation of the minimum requirements to the capital in addition to the system of calculation on the basis of risk. New coefficients of liquidity provide implementation of adequate financing in crisis situations.

Bankruptcy of a number of large international banks and banking groups has induced the Basel committee of bank supervision to establish obligatory international norms-principles concerning them in the special document carrying the name "Basel Concordat" ${ }^{\prime}$. In its basis the following norms-principles are:

- national bank authorities of the host country and country of origin on the consolidated basis have to carry out supervision of the international banks and the international banking groups;

- preliminary permission of the governing bodies of regulation and supervision to creation of the international bank organization will be settled by the bilateral memorandum signed by authorized the governing bodies of both countries;

- national authorities of regulation and supervision as host country, so countries of origin have rights of collection of information about the international banks and banking groups, which exchange between these bodies has to be carried out according to the principles of reciprocity and confidentiality;

- the right of the governing body of regulation and supervision of the host country when determining discrepancy of norms of law of the country of origin of bank the accepted international norms-principles - to forbid the international operations or to impose on them the restrictions corresponding to these norms-principles;

\footnotetext{
${ }^{8}$ The international-legal documents regulating activity of large international banks and banking groups "Basel Concordat", available at http://www.bis.org/press/p060406. htm. (date of viewing 6 November 2018).
} 
- an obligation of governing body of regulation and supervision of the country of origin of bank - to inform the governing bodies of the host country on change of the rules of law having substantial effects for the international operations of bank.

One of the most dangerous risks for participants of the global financial market is the risk of loss of reputation as reliable business partner in closely connected corporate ethics to the financial environment. There is so-called 'crisis of confidence'. He arises because of operational failures during the carrying out financial transactions, inability to carry out profitable activity only according to the legislation and also at emergence of suspicions of communications with criminal structures or in inability of financial management to effectively counteract legalization (washing) of income gained in the criminal way and terrorism financing and also other illegal activity.

In such situation the arising risk of insufficient liquidity caused by loss of business reputation results to risk of insolvency and loss of financial stability and, eventually, to the termination of activity of the financial organization. Problems of one financial organization affect at reputation of all national financial system of the state.

The Wolfsberg' principles ${ }^{9}$, which with good reason can be referred to the international norms-principles, contain the priority principles in activities of banks for prevention of use of a banking system for legalization of income, gained in the criminal way. The policy of bank has to be aimed at prevention of use of transnational operations for criminal intents.

The basis of the policy of any bank in this sphere of activity in accordance with the Wolfsberg' principles should be the normes according to which the bank can establish relations only with those clients have to be the cornerstone of policy of any bank, concerning sources of income or financing of activity of which their legal origin can be reasonably confirmed. At the same time Volfsberg' norms- principles assume that concrete mechanisms of counteraction to laundering of income gained in the criminal way can be determined by a discretion of bank ${ }^{10}$.

Legal regulation on the basis of the developed international financial and legal regulators does transparent and uniform requirements imposed to legal regulation of the relations in the sphere of finance in various states at the conditions of global economic space. And the changes connected with activity of a world financial turn, globalization of the monetary relations, leading to internationalization of financial crises and the necessity caused in this regard in international-legal regulation in this sphere of activity, directly affect the law-making process connected with adoption of the international integration acts governing the relations in the sphere of finance.

\footnotetext{
${ }^{9}$ Wolfsberg' norms-principles, available at: http://www.wolfsberg-principles.com / pdf / wolfsberg_aml_principles2.pdf. (date of viewing 6 October 2018).

${ }^{10}$ Wolfsberg' Statement Guidance on a Risk Based Approach for Managing Money Laundering Risks, available at: // http://www.wolfsberg-principles.com / pdf / wolfsberg_aml_principles2.pdf.
} 


\section{International-legal standardization of insurance activity}

Insurance is one of the most important components of the economic system of the state and can not be excluded from the process of global economic integration. For example, insurance of catastrophic risks due to their scale and the impossibility of making insurance these risks sometimes even in the whole country makes an irreversible process of integration of national insurance systems. Means of such integration are primarily reinsurance means that allow insurance companies to timely cope with virtually any size and complexity of the risks.

Globalization in the insurance sphere is shown in the following:

- formation of global insurance market as a component of the global economic market;

- the concentration of insurance capital, including the merging of insurance and banking capital, leading to the formation of transnational insurance corporations whose capital is increasingly seeks beyond national jurisdiction, and the size of assets and working capital of transnational insurance corporations are comparable to the budgets of separate countries;

- growth of international portfolio investment of insurance structures;

- increase in the number of international insurance transactions and, as a consequence of this, the expansion of the spectrum (the change of traditional forms and types) provided insurance services;

- regulation of the economic relations in the sphere of insurance by the rules of law having supranational/transnational character.

The basis of integration international-legal standardization of regulatory requirements for insurance companies make up: conditions of establishment of the insurance company; procedure for the formation of insurance reserve funds; conditions of investment money means of these funds; order of accounting and reporting requirements; regulation of a margin of solvency and financial stability of insurance companies and etc. Under the standards of the integration of international-legal regulation in the insurance sphere understands uniform requirements for insurance companies about providing their solvency and financial stability, aimed at protecting the interests of policyholders.

International Association of Insurance Supervisors (IAIS) has developed standards, establishing basic quantitative and qualitative parameters of the requirements for insurance supervision to the activities of insurance companies.

By the 'Methodology of the Basic Principles of Insurance' standard ${ }^{11}$ it is regulated: organization of insurance supervision and criteria of his implementation; conditions of licensing of insurance companies and their corporate management; adequacy of the capital and assets of insurance companies with their obligations, including derivatives and notes; conditions and principles of reinsurance and conduct trans-

\footnotetext{
${ }^{11}$ Methodology of the Basic Principles of Insurance available at http:// www.iaisweb.org. (date of viewing 6 November 2018)
} 
boundary transactions; financial reporting and auditing, including internal; financial monitoring; criteria for confidential information.

The basis "IAIS - Investments Subcommittee"12 — the norms-principles regulating investment activities of insurance companies including: investment policy and strategy of insurance companies; management of investment risks; property responsibility of insurance companies; financial monitoring and audit of investment activities, including internal control.

Besides, it should be noted, as professional associations of participants of the financial markets develop the international norms-principles, governing the relations in the financial sector of economy in spheres of the interests and competence - such as international organizations: International Accounting Standards Committee IASC, International Swaps and Derivatives Association - ISDA, International Securities Market Association - ISMA, Emerging Market Traders Association EMTA, Federation of European Risk Management Associations - FERMA, Risk and Insurance Management Society - RIMS and etc.

These institutions of international-legal integrated regulation at the areas of economics and finance are implemented in a united, integrative international legislation.

Moreover, the formation of the world's economic space, and as a result, the global market, in turn, puts forward for solutions of questions about globalization of governance in the sphere of economics and finance on the basis of the legal array of an international integrated law. Prototype of such global governance, carried out in the sphere of economics and finance, in our opinion, is currently formed at countries, that have acceded to the World Trade Organization (WTO).

\section{CONCLUSIONS}

Process of globalization not only is followed by gain of a role of international law as regulator of integration processes, but also promotes high-quality change of last. Changes are shown in subject and object spheres, methods of legal regulation and the functional directivity of international law.

In the subject sphere. Expansion of structure of the international relations due to inclusion of the mixed relations (between the states and non-state entities) and the non-state relations has led to emergence of new subjects of international law: nongovernmental organizations, individuals, multinational corporations, administrativeterritorial educations (subjects of federations), international judicial.

Institutions though having the smaller volume of legal personality in comparison with the states (the main subjects of international law). Owing to this fact the in-

\footnotetext{
${ }^{12}$ IAIS - Investments Subcommittee. available at http:// www.iaisweb.org. (date of viewing 6 November 2018).
} 
ternational law is lost by the purely interstate character, being transformed to the international integration law.

In the object sphere. As it was already specified, an object of international law is mobile and extends as due to appearance of new areas of interstate cooperation (a cyberspace, genetic engineering), and by regulation of the questions which were earlier in exceptional competence of the state. Human rights, environment protection, economy, defense, political system concern them. Practically any question at will of the states can become a subject of joint regulation of the international and national law.

Distribution of the regulating influence of international law on a scope of national jurisdiction especially brightly is shown in a regulation of economic problems. So, for example, send questions of application of tariff and non-tariff restrictions, to intellectual property, investment measures, environmental standards to competence of the WTO. The states have transferred regulation of the questions connected with exchange rates and balances of payments to competence of the IMF.

Methods of legal regulation. Expansion of a circle of subjects of international law has led to new methods of international legal regulation. Along with a traditional method of coordination of cooperation at the horizontal level as equal subjects the method of subordination (taxonomy) operating at the vertical level (for example, between governing bodies of the EU and member-states and their physical persons and legal entities) and also at the diagonal level between public subjects of law (the state, the international intergovernmental organization) and private subjects of law (individuals, legal entities, non-governmental organizations) is widely used.

The international law has played an important role in ensuring legal equality of the states though their actual inequality especially in respect of social and economic development continues to remain and go deep into a globalization era, being a source of local armed conflicts, the reason of growth of transnational crime and activization of the international terrorism.

Thus, globalization of world economy promotes, on the one hand, creation of a common economic space, and with another - to formation of the corresponding international-legal integration superstructure. In particular, the situation connected with cross-border concentration of identical resources demands from the states of coordination of actions in international legal antimonopoly regulation of the commodity markets, as well as maintenance of fair competitive conditions for joint ventures of the different countries.

\section{БИБЛИОГРАФИЧЕСКИЙ СПИСОК / REFERENCES}

Abashidze, A.H. and Lukashuk, I.I. (2001), Globalization, state, law, 21st century // State and law, p. 113.

Alekseev, S.S. (1999), Civil law in present period. Moscow: Norma, p. 40.

Berger K.P. (1999). The Creeping Codification of the Lex Mercatoria, Kluwer Law International. London, Boston: The Hague, p. 376. 
Bogatyryov, V.V. (2006), Global law as natural stage of legal development// Messenger of the Ivanovo state power university, p. 51.

Bogatyryov, V.V. (2013). Global level of legal integration // Messenger of the Vladimir plegal institute 3 (28), pp. 128-133.

Bogatyryov, V.V., Gorshkova, N.A. (2010), The principles of the law as a basic element of the global law // Gaps in the Russian legislation 1, p. 51.

Dmitriyeva, G.K., Lukashuk, I.I. (1995), Formation of the international standard system // Russian year-book of international law, p. 7.

Egorov, S.A. (2014), International law, 5th ed. Publishing house: Statut, p. 1087.

Farkhutdinov, I.Z. (2003), International law in the conditions of globalization // Law and policy, p. 141.

Farkhutdinov, I.Z. (2004), Globalization and geo-economics: new legal paradigms of world order // Legislation and economy, p. 18.

Farkhutdinov, I.Z. (2005), International investment law. Theory and practice of application. Moscow: Volters Kluver, p. 463.

Farkhutdinov, I.Z. (2009), Euroasian legal space: problems and ways to overcome them // Euroasian legal journal, p. 4.

Farkhutdinov, I.Z. (2010), International investment law and process. Moscow: Prospekt, p. 415.

Hartkamp, A.S. (1994), The Unidroit Principles for International Commercial Contracts and the Principles of European Contract Law // European Review of Private Law, p. 16.

Kalamkaryan, R.A. (2002), Concept of the state of law // State and Law, pp. 57, 60.

Klepatsky, L. (2002), Globalization and national interests // International life, 34 p. 37.

Knop, K. (2000), Here and There: International Law in Domestic Courts // New York University Journal of International Law and Politics, p. 506.

Kochetkov, E.G. (2005), Geoeconomics. Moscow, p. 211.

Koh, H. (1996). Transnational Legal Process // Nebraska Law Review, p. 75.

Lando, O., Clive, E., Prum, A., Zimmermann, R. (2003), The Principles of European Contract Law. London, Boston: The Hague.

Lukashuk, I.I. (1997), International criminal law and legal system of Russia // Journal of Russian law, p. 33.

Lukashuk, I.I. (2000), Democracy - the principle of the international community of XXI century // State and law at the turn of the century. Materials of the All-Russian conference of international law.

Lukashuk, I.I. (2001), Codification and progressive development of international law in the 21st century'. Russian year-book of international law, pp. 9, 68.

Lukashuk, I.I. (2001), Globalization and state // Journal of Russian law, p. 64.

Lukashuk, I.I. (2002), Interaction of the international and internal law in the conditions of globalization // The Journal of Russian law, pp. 115, 117.

Lukashuk, I.I. (2002), World order of the XXI century // International public and private law, 4. pp. 4-5.

Lukashuk, I.I. (2004), Law of the international responsibility. Moscow: Volters Kluver.

Lukashuk, I.I. (2005), Democracy - the principle of the international community XXI of century. State and law at the turn of the century // International law. Moscow, p. 518.

Lukashuk, I.I. (2005), Interaction of the international and internal law. Moscow.

Lukashuk, I.I. (2005), International law, 3th ed. Moscow: Volters Kluver, p. 432.

Maksimenko, V. (1999), Whether there is "globalization"? // Pro et Contra, p. 13.

Marochkin, S.U. (1997), A ratio of validity of norms of the international and internal law in the legal system of the Russian Federation // Moscow journal of international law. 
Moiseyev, A.A. (2006), International financial institutions. Legal aspects of activity. Moscow, p. 234.

Moiseyev, A.A. (2015), Phenomenon of globalization and international community // Century of globalization, p. 59.

Muellerson, R. (2000), Ordering Anarchy. International Law in International Society. The Hague, p. 199.

Polenina, S.V. Gavrilov, O.A. and Koldayeva, N.P. (2004), Impact of globalization on the legal system of Russia // State and Law, p. 5.

Schmitthoff, C. (1963), The New Sources of the Law of International Trade // International Social Science Journal.

Shumilov, V.M. (2003), 'Law of the WTO and international law // Moscow journal of international law, p. 16.

Shumilov, V.M. (2003), Concept of global legal system // International lawyer, p. 46.

Soros, J. (1999). Crisis of world capitalism. Open society is in danger. Moscow, p. 326.

Tikhomirov, U.A. (1996), Course of comparative jurisprudence. Moscow: Norma.

Tikhomirov, U.A. (2004), About modernization of the state // The Journal of Russian law, pp. 3, 7.

Tiunov, O.I. (1999), International humanitarian law. Moscow, p. 254.

Toynbee, A.J. (1995), A civilization before court of history. Moscow.

Tunkin G.I. (1982), International law. Moscow, p. 628.

Yavich, L.S. (2003), About legal philosophy for the 21st century // Jurisprudence, pp. 38, 40.

\section{Information about the authors:}

Andrey A. Mamedov - Doctor of Law, Professor, Professor of Department of administrative and financial law of Peoples' Friendship University of Russia

ORCID ID: 0000-0002-1761-5461

Contact information:

e-mail: profit33@mail.ru

Vera N. Batova - Candidate of Economic Sciences, Associate Professor, Associate Professor of Department of Economics and management of Penza State Technological University

ORCID ID: 0000-0003-0484-0819

Contact information:

e-mail: batova.v.n@yandex.ru

\section{For citation:}

Mamedov, A.A., Batova, V.N. (2019), International law in the context of economic globalization (EAC), RUDN Journal of Law. 23 (2), pp. 264-288. DOI: 10.22363/2313-2337-2019-232-264-288.

Article received May 20, 2019

Article accepted May 30, 2019 


\title{
МЕЖДУНАРОДНОЕ ПРАВО В УСЛОВИЯХ ГЛОБАЛИЗАЦИИ МИРОВОЙ ЭКОНОМИКИ
}

\author{
А.А. Мамедов \\ Российский университет дружбы народов \\ Юридический институт \\ 117198, Москва, Россия, ул.Миклухо-Маклая, д. 6
}

\begin{abstract}
В.Н. Батова
Пензенский государственный технологический университет 440039, Пенза, Россия, проспект Байдукова, ул. Гагарина, д.1а/11
\end{abstract}

Современная эпоха - это эпоха глобализации, включающая в себя высокодинамичное развитие интеграционных процессов в различных сферах деятельности государства.

В условиях глобализации национальные экономические системы активно интегрировались в единый планетарный механизм с универсальной системой экономических институтов и взаимодействия рынков.

По нашему мнению, глобализация представляет собой процесс стирания не только экономических границ, но и границ национальных юрисдикций между государствами. Правовой аспект глобализации проявляется, на наш взгляд, прежде всего в том, что все больше и больше вопросов внутренней юрисдикции передаются государствами на наднациональное регулирование. Формирование глобального экономического пространства - важнейший аспект, интенсифицирующий процесс стирания границ национальных юрисдикций.

Поэтому, рассматривая правовое регулирование отношений в экономическом и финансовом сегментах деятельности государств в современный период, нельзя не учитывать мировые интеграционные процессы в процессе глобализации, приводящего к созданию целостного законодательства, подчиняющегося единой правовой логике и требующего учета как неолиберальных мировых тенденций в праве, так и разнообразную природу национальных правовых систем. Глобализация объективно ведет появлению наднациональных/транснациональных элементов правового регулирования. усилению в праве роли именно международных интеграционных аспектов.

В развитии права в условиях глобализации можно выделить следующие основные тенденции его развития, прежде всего:

первое - тенденция к унификации права, проявляющаяся в стремлении выработки общего, всеобъемлющего подхода к праву, означающего введение в правовые системы государств единообразных, унифицированных норм;

второе - в условиях экономической глобализации прослеживается тенденция к все более широкому формированию и более активному использования международных нормпринципов права как регуляторов в сфере экономических и финансовых отношений, играющих активную роль в системе регулятивных средств, используемых на глобальном и региональном уровнях;

третье - в условиях глобализации право становится все более сложной системой и предусмотреть все в законах невозможно, поэтому неизбежно повышается роль судебной практики - судебного прецедента в решении вопросов, связанных с правовым регулированием экономических и финансовых отношений.

При этом необходимо отметить, что наука международного права и договорная практика в отношении общепризнанных норм-принципов международного права исходят из того, что действует единый императивный принцип добросовестного соблюдения международных обяза- 
тельств (применительно к международным договорам он именуется принципом pacta sunt servanda).

В условиях глобализации мировой экономики именно глобализация правового пространства будет способствовать нивелированию особенностей национальных законодательств вследствие применения унифицированных норм формируемого международного интеграционного права.

Понимание принципов международного интеграционного права позволяет упростить процесс правового регулирования отношений в сфере экономики и финансов в условиях экономической глобализации, включая и заключение договоров, определение условий их исполнения и быстрое решение возникающих между контрагентами споров, в том числе, в частности, и в рамках института международного интеграционного права Lex mercatoria.

Ключевые слова: экономика, финансы, банковская деятельность, международное право, международные нормы-принципы, глобализация, мировое экономическое пространство, унификация права, интеграция, соглашение

Информация о финансировании. Статья подготовлена при поддержке «Университетской программы РУДН 5-100».

\section{Сведения об авторах:}

Мамедов Андрей Алиевич - доктор юридических наук, профессор, профессор кафедры административного и финансового права Юридического института Российского университета дружбы народов

ORCID ID: 0000-0002-1761-5461

Контактная информация:

e-mail: profit33@mail.ru

Батова Вера Николаевна - кандидат экономических наук, доцент, доцент кафедры экономики и управления Пензенского государственного технологического университета

ORCID ID: 0000-0003-0484-0819

Контактная информащия:

e-mail: batova.v.n@yandex.ru

\section{Для цитирования:}

Мамедов А.А., Батова В.Н. Международное право в условиях экономической глобализации // Вестник Российского университета дружбы народов. Серия: Юридические науки. 2019. Т. 23 № 2. С. 264-288. DOI: 10.22363/2313-2337-2019-23-2-264-288.

Дата поступления в редакиию: 20 Мая 2019

Дата принятия к печати: 30 Мая 2019 